\title{
Evaluation of Extension Agents Commitment to the Agricultural Loans and Inputs Supply Programme on Special Rice Production in Delta State, Nigeria
}

\author{
${ }^{* 1}$ OKWUOKENYE, GF; DU. OKOEDO-OKOJIE ${ }^{2}$ \\ ${ }^{I}$ Dept of Agric Economics \& Extension Faculty of Agriculture Ambrose Alli University PMB 14, Ekpoma, Nigeria Email: \\ goddyviv@yahoo.co \\ ${ }^{2}$ Dept of Agricultural Economics \& Extension Services Faculty of Agriculture University of Benin P.M.B. 1154 Benin City, Nigeria Email:
}

KEY WORDS: Extension agents, agricultural production, inputs, loans, technologies, evaluation

ABSTRACT: The study evaluated the activities of Extension agents on Agricultural Loans and Inputs Supply Programme participant farmers' rice output/income. Data were collected with the aid of questionnaire from 60 Extension agents (participating in the ALIS programme) randomly selected from 6 LGAs (where the programme is being implemented) of Delta State. Data were also collected from 80 participant and 80 nonparticipant farmers' of the programme. Results of data analysis reveals that all the Extension agents are males and are married. Most (40\%) of them belong to the age bracket of $30-39$ years, with a high proportion (48.3\%) of them having $\mathrm{HND} /$ first degree and a good number of them (28.3\%) having $5-6$ years experience in the ALIS programme. Major functions carried out by the Extension agents in the ALIS programme were advisory role (2.75), training farmers on inputs use (2.67) and demonstrating inputs use (2.65). The roles of the Extension agents on the farmers made a significant difference in out $(176.25 \mathrm{~kg})$ and income $\$ 53,468.75$ in favour participants. Important inputs provided by the extension agents are farm size, improved seeds and farm chemicals like fertilizer and urea. Some important constraints facing the programme according to the Extension agents were limited coverage of farmers (3.23), wrong selection of programme participants (3.22), late delivery of inputs (3.15) and poor funding of the programme (3.05). Based on findings the study recommends that efforts should be made to deliver inputs promptly to farmers, ensure all necessary inputs are timely made available to farmers and in adequate quantities, there is need to ensure that only those farmers who depend on rice farming are selected to participate in the programme. (C JASEM

http://dx.doi.org/10.4314/jasem.v18 i2.25

Introduction: Agricultural Extension agents are primarily concerned with the transmission of improved agricultural technologies to farmers who are the end users of all findings emanating from agriculture related researches as well as taking their problems to appropriate research or government agency for solution (Erie, 2009). He noted that agricultural extension is an educational process designed for farmers to enable them adopt improved practices and by so doing raise standard of living through their own efforts and using their own resources. Extension agents are described as the major tool in the implementation of various projects designed by each State Agricultural Development Programme (ADP) in Nigeria to improve agricultural production and income of rural farmers (Agumagu and Nwaogwugwu, 2006). To achieve this above stated goal, the ADPs depend on the services carried out by the Extension agents who are saddled with various extension responsibilities in the rural areas. Such duties include the dissemination of updated and useful information on recent innovations, agricultural policies affecting the farmers, improved production methods, better marketing alternatives, sources of improved farm inputs, etc.

For the Extension agents to succeed in carrying out the above assignment, Adams (1992) emphasized that they need to be committed and show positive work behaviours which must include strong commitment to their job. He asserted that this is so because most of the time the Extension agents are expected to work unsupervised and the work required a great deal of patience and persistence. Unfortunately, most evaluation studies carried out much earlier to determine the Extension agents level of effectiveness in meeting the challenge of providing efficient extension services tended to conclude that the Extension agents did not make any remarkable impact on the agricultural scene especially in developing countries of which Nigeria is one (Eicher, 2001). Hence the study concerns itself with the costs of extension services rendered to farmers against the economic and social returns associated with successful extension. 
The Agricultural Loans and Inputs Supply Progarmme (ALIS) on special rice production was launched by the Federal Government in 1998 (DADP, 2001). The report noted that the programme involved the cultivation of 50 ha. of land per state annually, with a main objective of boosting rice production in the country. The programme is operated in conjunction with the different States Agricultural Development Programm (ADPs). Under the programme loans and inputs like improved planting seeds, fertilizer, agro-chemicals, knapsack sprayers, fertilizer spreaders, rice reapers and sickles are provided for rice farmers to improve rice production in the country.

Boumas (1994) noted that about $20 \%$ of rough rice consists of husks after milling which issed primarily as beddings and as loosed insulating material. The rice bran is rich in nutrients and is used in baby food preparation. Thus, rice is a raw material for local agro based industries. Sanusi (2003) emphasized that good quantity and quality production of rice is crucial to ensuring food security in the country. He further emphasized that rice is an important crop whose surplus production would lead to export and thus attract foreign exchange earnings and consequently play its pivotal role in economic development.

Several studies may have been carried out on rice production but none has focused on its production in relation to assessment of Extension agents with particular reference to the Agricubbbltural Loans and Inputs Supply (ALIS) Programme. The study therefore seeks to:Examine the socio - economic characteristics of Extension agents serving in the Agricultural Loans and Input Supply Programme in Delta State. Examine the Extension agents experience (years) in the Agricultural Loans and Input Supply Programme in the State. Examine the roles of Extension agents in the Agricultural Loans and Input Supply Programme and their effects on rice output/income of farmers in the Delta State.bAscertain the Extension agents' perception of the challenges faacing the ALIS programme.

Hypotheses of the study: he null hypotheses that were tested in the study are as follows: There is no significant relationship between socio-economic characteristics of the Extension agents and the ALIS programme participants' status on output/income of rice farmers. There is no significant relationship between inputs provided by Extension agents' and output/income of rice farmers programme participants.

\footnotetext{
${ }^{*}$ OKWUOKENYE, GF; DU. OKOEDO-OKOJIE ${ }^{2}$
}

Methodology: This study was carried out in Delta State. The State has 25 Local Government Areas with the capital at Asaba. Its population is 4,170,214 based on the 2006 census figures (AWC, 2006). Geographically, the State is accommodated between longitudes $5.00^{\circ}$ and $6.45^{\circ}$ North and latitudes $18^{\circ}$ and $23^{\circ}$ South. It is flanked by Edo State to the North, Ondo State to the North-West, Anambra State to the East and it is bounded in the South by the Bight of Benin and has an Atlantic Coastline of $160 \mathrm{~km}$ (MANR, 1998). The State is made up of diverse ethnic and tribal groups and mostly inhabited by the Isoko, Ika, Urhobo, Itshekiri, Ijaw, Ukwuanis, and Aniocha speaking people. Their predominant occupation is farming which encompasses fishing, cropping and animal rearing. Besides farming, the inhabitants also engage in various other occupations such as oil prospecting, civil service, trading and commerce (AWC, 2006).

Agriculturally, Delta State is divided into three agricultural zones, namely Delta North, Delta Central and Delta South. These zones, respectively, have 9, 10 and 6 Local Government Areas with 72, 80 and 48 communities, respectively. The Delta State Agricultural Development programme has its Headquarters at Ibusa.

The Agricultural Loans and Inputs Supply Programme on Special Rice production in Delta State is presently conducted in six Local Government Areas in the State, namely Oshimili North, Oshimili South, Ndokwa West, Sapele, Patani and Isoko North. All the villages in which the programme is implemented were purposively sampled because of the small size (only 10). The number of rice farmers participating in the programme per community is ten. Thus, a total of 100 farmers are participating in the programme State-wide. Eighty percent $(80 \%)$ of these were randomly sampled, i.e. 80 participants in all. For the purpose of comparism, an equivalent number of rice farmers not participating in the programme were randomly sampled from the communities in the project areas. Thus, a total of one hundred and sixty (160) farmers were sampled for the study. Through personal communication, the agency (ADP) noted that about 80 Extension agents are involved in the ALIS programme State wide. From the 80,70 of them were randomly sampled and administered with questionnaire. Out of these sampled, 60 of them suitable for analysis were compiled and analyzed.

The validated instruments were tested for reliability. A reliability coefficient (Cronbash Alpha) of 0.773 
and 0.845 were reported for the farmer and Extension agent question instruments

Descriptive statistics (frequency distribution, percentage and mean) were used for analyzing the socio-economic characteristics of the respondents. Inferential statistics (multiple regression and t-test) were used to test the hypotheses of the study. Multiple regression was used to determine the effect of household characteristics of the Extension agents' and the ALIS programme participants on output/income of farmers. The regression equation is specified as: $Y=a+b_{1} X_{1}+b_{2} X_{2}+b_{3} X_{3} \ldots+b_{n} X_{n}+$ e; Where $\mathrm{Y}=$ dependent variable; $\quad \mathrm{a}=$ coefficient $\mathrm{X}_{1}=$ independent variable; $\mathrm{e}=$ error term; The variables in the equation are defined below:; $\mathrm{Y}=$ Income $\left(\AA\right.$ ) from rice production; $X_{1}=$ Gender (male $=1 ;$ female $=0) ; X_{2}=$ Age (years); $X_{3}=$ Marital status; $\mathrm{X}_{4}=$ Education level (years); $\mathrm{X}_{5}=$ Household size (number of people living and feeding together); $\mathrm{X}_{6}=$ Working experience (years)

$\mathrm{X}_{7}=$ ALIS Participation status (participants $=1$; nonparticipants $=0$ ); Multiple regression was also used to estimate the determinants of income of the ALIS participants and this was based on the production inputs provided by the ALIS programme. The regression equation is specified as: $Y=a+b_{1} X_{1}$ $+b_{2} X_{2}+b_{3} X_{3} \ldots+b_{n} X_{n}+e ; Y=$ dependent variable; $\mathrm{a}=$ coefficient $; \mathrm{x}_{1}=$ independent variable; $\mathrm{e}=$ error terms; The variables in the equation are defined below: $Y=$ income ( $)$ of participants from rice production; $\mathrm{X}_{1}=$ farm size; $\mathrm{X}_{2}=$ cost of improved seeds; $\mathrm{X}_{3}=$ cost of chemicals

Different functional forms which include, linear, exponential, Cobb Douglas and semi-log were first tested to select the best fit model. The best fit model or lead equation was selected based on the model with the highest adjusted $\mathrm{R}^{2}$ with most likely the highest $\mathrm{F}$ - ratio and a t-value that shows level of significance of the variables being tested (Olayemi, 1998). The t- test was used to compare the difference in means of two variables or items. This test was used to test the effect of the ALIS programme policy on rice production in the country. It was equally used to determine the significance of the difference in income of ALIS participants and non-participants.

The constraints perceived by the Extension agents to be facing participants in the ALIS programme were measured on a 4-point Likert scale. The scale range is from, Very serious coded 4, serious (3), not too serious (2) and not a problem at all (1). The weighted mean score was used to determine which constraints were serious and not serious. The weighted mean score (2.50) was obtained as follows: $(4+3+2+$
$1) / 4=2.50$. Constraints with values of 2.50 and above were considered serious, while those with values less than 2.50 were regarded as not serious.

Also the functions or roles performed by extension agents in the ALIS programme were measured on a 4 point likert scale. To determine which functions are regular or not, the weighted mean of 2.50 was used. The functions with means 2.50 and above were termed regular implying that these functions were regularly carried out by the extension agents, while functions with means of less than 2.50 indicates the functions were not regularly carried out.

\section{RESULTS AND DISCUSSION}

Socio-economic characteristics of respondents: The data on socio-economic characteristics of Extension agents participating in the ALIS programme are presented in Table 1. They are all males. The dominance of males in the ALIS programme reflects the predominance of male Extension field staff in the State. Similar results have been obtained by Agumagu and Nwaogwugwu (2006), who noted that male Extension agents formed the bulk of the workforce in the agricultural extension service in the Niger Delta states such as Abia and Rivers States. All the Extension workers are married, with the majority (40\%) between $30-39$ years old. The mean age was 44 years indicating that they are young and active. They will therefore be able to execute the extension work related to the ALIS programme.

Almost half of them (48.3\%) have Higher National Diploma HND / First degree, 21.7\% and 30\% of them had Ordinary National Diploma (OND) and school Certificate respectively. The average schooling years of the respondents was 14 years. This suggests a high educational level among them. They will therefore be able to work with the innovations associated with the ALIS programme i.e. understand their use and been able to communicate it to the farmer. The household size of the extension agents shows a mean of 4.15 persons, indicating that they have an average household size which will encourage them to do their job.

The modal (50\%) working experience of the extension agents was $5-9$ years, with an average of 10 years, which indicates that they are experienced in extension work. They are thus in a position to know the needs and problems associated with extension practice in the study areas especially where the ALIS programme is implemented

Almost half of them $(48.3 \%)$ have Higher National Diploma HND / First degree, $21.7 \%$ and $30 \%$ of

${ }^{*}$ OKWUOKENYE, GF; DU. OKOEDO-OKOJIE ${ }^{2}$ 
them had Ordinary National Diploma (OND) and school Certificate respectively. The average schooling years of the respondents was 14 years. This suggests a high educational level among them. They will therefore be able to work with the innovations associated with the ALIS programme i.e. understand their use and been able to communicate it to the farmer. The modal $(50 \%)$ working experience of the extension agents was $5-9$ years, with an average of 10 years, which indicates that they are experienced in extension work. They are thus in a position to know the needs and problems associated with extension practice in the study areas especially where the ALIS programme is implemented

Table1: Socio - economic characteristics of Extension agents

\begin{tabular}{lllll}
\hline Characteristics & Categories & Freq. & $\%$ & Mean \\
\hline Sex & Male & 60 & 100.00 & \\
Marital status & Total & 60 & 100.00 & \\
& Married & 60 & 100.00 & \\
Age (years) & Total & 60 & 100.00 & \\
& $30-39$ & 24 & 40.00 & \\
& $40-49$ & 19 & 31.70 & \\
Educational status & $50-59$ & 17 & 28.30 & \\
& Total & 60 & 100.00 & 44 \\
& Secondary & 18 & 30.00 & \\
& OND & 13 & 21.70 & \\
& HND/First & 29 & 48.3 & \\
Working & degree & 60 & 100.00 & 14 \\
experience (years) & Total & 30 & 50.00 & \\
& $5-9$ & & & \\
& $10-14$ & 24 & 40.00 & \\
& $15-19$ & 6 & 10.00 & \\
& & & & \\
Household size & Total & 60 & 100.00 & 10 \\
& $1-3$ & 21 & 35.00 & \\
& $4-6$ & 35 & 58.33 & \\
& $7-9$ & 4 & 6.67 & \\
& & & 100.00 & 4.15 \\
\hline \multirow{5}{*}{ Total } & 60 &
\end{tabular}

Extension agents experience (years) in the ALIS programme: Table 2 shows the number of years the Extension agents have been participating in the ALIS programme. The highest proportion of the agents (28.3\%) have been involved in the ALIS programme for $5-6$ years, $21.7 \%$ have been involved for $7-8$

Table 2: Extension agents experience (years) in the ALIS programme

\begin{tabular}{lll}
\hline Experience (years) & Frequency & Percent \\
\hline $1-2$ & 10 & 16.7 \\
$3-4$ & 8 & 13.3 \\
$5-6$ & 17 & 28.3 \\
$7-8$ & 13 & 21.7 \\
$9-10$ & 12 & 20.00 \\
Total & 60 & 100.00 \\
\hline
\end{tabular}

Source: Field survey, 2012

Extension agents' role in the ALIS programme.: The extension agents' role in the ALIS programme is shown in Table 3. The results show that, advisory role $($ mean $=2.75)$, training farmers $(2.67)$, and demonstrating input used by farmers (2.65), have means greater than 2.50. This indicates that these roles were regularly carried out by the agents.

\footnotetext{
${ }^{*}$ OKWUOKENYE, GF; DU. OKOEDO-OKOJIE ${ }^{2}$
}

years, $20 \%$ for $9-10$ years, $13.3 \%$ have been for $3-$ 4 years while $16.7 \%$ for only $1-2$ years. The result suggests that they are experienced in the programme. Thus, the agents are in a position to know the problems associated with the ALIS programme.

Table 3: Extension agents' role in the ALIS programme

\begin{tabular}{lll}
\hline Role & Mean & SD \\
\hline Advisory role & $2.75^{*}$ & 0.57 \\
Farmer training on input use & $2.67^{*}$ & 0.84 \\
Demonstrating inputs use & $2.65^{*}$ & 0.71 \\
Input distribution & 1.87 & 0.62 \\
\hline
\end{tabular}

*Regular (mean>2.50)

Difference in Rice Output of ALIS Participants and Non-Participants:Table 4 shows the $\mathrm{t}$ - test result for the difference in rice output of the ALIS participants and non-participants. The result shows that the average rice output of participants was $840.0 \mathrm{~kg}$ while that of the non-participants was $663.75 \mathrm{~kg}$. The $\mathrm{t}-$ test value (4.992) shows that the difference in the quantity produced $(176.25 \mathrm{~kg})$ is significant at the $1 \%$ 
level (critical $t=2.36$ ). This suggests that ALIS programme contributes positively and significantly to output of rice farmers in the study area. The difference in the output level can be attributed to the inputs and improved technologies as well as the role of Extension agents provided by the ALIS programme. This finding supports that of Ajayi and Okunlola (2006), which noted that the use of improved varieties of crops and modern technologies significantly influence the production of crops.

Table 4: Difference in rice output between Participant and Non-participant farmers'

\begin{tabular}{llll}
\hline Status & Output & Difference & t-value \\
\hline Participants & 840 & & \\
Non- participants & 663.75 & $176.25 *$ & 4.992 \\
\hline \multicolumn{4}{c}{ * Significant at $1 \%$, (critical $t=2.36)$}
\end{tabular}

Difference in Income of ALIS Participant and Nonparticipant Farmers': Table 5 shows the income realized from rice production by the participants and non-participants of the ALIS programme. The result shows that the average revenue realized from rice production by participants was $\$ 140,447.50$ while that of the non-participants was $\$ 86,978.75$. The result shows that the difference in the revenue of participants and non-participants was significant at the $1 \%$ level (critical $t=2.36$ ). As earlier noted, the difference is attributed to the adoption of improved technologies by the participants

Table 5: Difference in Income of ALIS Participant and Non-participant Farmers'

\begin{tabular}{llll}
\hline Status & Income & Difference & t-value \\
\hline Participants & $140,477.50$ & & \\
Non-participants & $86,978.75$ & $53,468.75^{*}$ & 9.831 \\
\hline
\end{tabular}

$*$ Significant at $1 \%$ (critical $t=2.36$ )

Influence of Extension Agents Socio-Economic Characteristics And Participant Status On Income Of Rice Farmers: Table 6 shows the estimated parameters of factors affecting income of rice farmers. The exponential regression function was adopted as the most appropriate or lead equation based on its adjusted $R^{2}$. Seven (7) of the explanatory variables were significant at the $1 \%$ level. These variables were ALIS participants' status, age, marital status, educational status, household size and working experience. The variables in the model jointly account for about $90.9 \%$ variation in income of the respondents (adjusted $\mathrm{R}^{2}=90.9 \%$ ). The computed F - Statistics (172.783) is significantly high at the $1 \%$ level, denoting that the collective influence of these variables on respondents' rice income is significant. The results are further discussed below.

The determinants of rice income of ALIS participants are arranged in their order of importance based on their standardized coefficient. ALIS participant status (beta $=0.927$ ) exacts the strongest influence on the income level of the farmers. The coefficient is positive, confirming the positive impact of the ALIS programme on income of rice farmers in the study area. The $\mathrm{t}$ - value (9.071) is significant at the $1 \%$ probability level $(\mathrm{P}<0.01)$, indicating that ALIS programme has a significant effect on income of rice farmers. The report of Agbamu (1993), confirms this finding and he noted that extension training programmes of which ALIS programme is an example, is known to impact positively on technology adoption and income of the farmer participants.

The second major determinant of income is gender (beta $=0.489$ ). It is positively signed and significant at the $1 \%$ level $(\mathrm{t}$ value $=13.942)$. The result reflects the dominance of males in the programme, this makes it possible for the extension agents to do their work very well. Thus making it a duty on the farmers to grow more rice, realize more output and earn higher income. This report supports that of Agumagu and Nwaogwugwu (2006) who found that the dominance of males in agricultural programmes brings about commitment which translates to higher output.

Marital status was the third factor influencing farmers output and income. It is positively signed (beta $=0.476, t=12.061)$ and significant at the $1 \%$ level. Being married makes the extension agents to be responsible to themselves and to their job thus imparting positively on the farmers' income. Agumagu and Nwaogwugwu (2006) noted that the married people impart more on farmers than the unmarried who most times fell unsecured in their jobs.

Following marital status is the age of the extension agents (beta $=0.411$ ) also had a positive and significant relationship with income at the $1 \%$ level $(\mathrm{t}$ $=10.030)$. The positive sign suggests that older

${ }^{*}$ OKWUOKENYE, GF; DU. OKOEDO-OKOJIE ${ }^{2}$ 
extension agents tend to be more experienced and may have likely participated in similar programmes and so be in a better position to assist the farmer in realizing higher output. This report is in line with that of Yomi-Alfred (2005) which noted that the more farmer workers are in age, the more experienced they tend to be in their farming activities and possibly the higher their farm income.

Table 6: Relationship between socio-economic characteristics and participant status on income of rice

Farmers

\begin{tabular}{llll}
\hline $\begin{array}{l}\text { Explanatory } \\
\text { variables }\end{array}$ & $\begin{array}{l}\text { Unstandardized } \\
\text { Coefficients (B) }\end{array}$ & $\begin{array}{c}\text { Standardized } \\
\text { Coefficients (Beta) }\end{array}$ & t-value \\
\hline Constant & 12.064 & & 124.981 \\
ALIS participant status & 0.943 & 0.927 & 9.071 \\
Gender & 0.135 & 0.489 & 13.942 \\
Marital status & 0.131 & 0.476 & 12.061 \\
Age & 0.084 & 0.411 & 10.030 \\
Educational status & 0.015 & 0.152 & 5.127 \\
Working experience & 0.013 & 0.138 & 4.088 \\
Household size & 0.001 & 0.138 & 0.026 \\
\hline
\end{tabular}

Adjusted $R^{2}=0.909, F-$ Statistics $=172.783$

Significant at $1 \%$ level, Critical $F=6.63$

A positive and significant relationship (beta $=0.152$, $\mathrm{t}=5.127$ ) exist between educational status of the extension agents and the farmers' income. This implies that the more educated the extension agents are, the more they are able to manipulate farm activities and thus be able to come out with better results. Education enhances extension agents' capacity to appreciate and comprehend the use of modern farm technologies that enhances output and income. This is in agreement with the findings of Eze et al (2006). Working experience $(\mathrm{b}=0.138, \mathrm{t}=$ 4.088 ) is the sixth determinant of the farmers' output and income. It is positively signed and significant at the $1 \%$ level. The implication is that the more working experience they have, the more they are able to impart positively on the farmers ability to understand extension packages which results to higher output of the farmers. Agumagu and Nwaogwugwu (2006) supported this finding when they noted that extension agents with more working experience tend to perform better than new entrants into the job.

Household size of the extension agents' (beta $=$ 0.001 ) is the seventh major determinant of rice income of the farmers', and it is positive and statistically significant at $1 \%$ level $(\mathrm{t}=0.026)$. This means that extension agents an average household tend to be focused in their jobs and function adequately in extension programmes. Economic implication of the result is that extension agents' with such a household size would be willing to do their jobs and earn income from their employer and possibly some level of gratitude from the famers' they serve. This result supports that of Mgbada (2006) who recognized that extension agents with

\footnotetext{
${ }^{*}$ OKWUOKENYE, GF; DU. OKOEDO-OKOJIE ${ }^{2}$
}

responsibilities would take their work seriously and this will result to higher output of the farmers'.

Influence of inputs provided by extension agents and output of rice farmers: The influence of the inputs provided by extension agents and the output of rice farmers in shown in Table 7. The table shows the estimated parameter of inputs employed by the extension agents participating in the programme. Out of the regression functions used, the exponential function was adopted as the lead equation based on its adjusted $R^{2}$ and $F$ - ratio. The inputs provided by the programme were significant. Cost of improved seeds and farm size (ha) were significant at the $1 \%$ level while cost of farm chemicals (fertilizer and urea) was significant at the $5 \%$ level. The variables in the model jointly account for about $79.8 \%$ variation in income (adjusted $\mathrm{R}^{2}=79.8 \%$ ). The computed $\mathrm{F}$ ratio (105.161) is significant at the $1 \%$ level (critical $\mathrm{F}=6.63$ ), implying the model is appropriate for the analysis. The result is discussed below.

The determining factors of the rice income of ALIS participants are arranged in their order of importance. Farm size provided by the extension agents exacts the strongest influence on their income. The coefficient is positive, implying that the larger the farmer's farms the more income they are likely to realize. Its beta value $(0.858)$ is significant at the $1 \%$ level $(\mathrm{t}=$ 16.492). This finding support Nwakalobo (2000) and Adeniyi (2002) who found that increase in farm size results to an increase in farm income.

The second major determinant of rice income of the ALIS participants is cost of improved seeds provided by the programme. The beta coefficient $(-0.188)$ is significant at $1 \%$ level $(\mathrm{t}=-2.624)$. The result is 
negatively signed suggesting that more investment in seeds is expected to exert a downward trend on income. The negative sign simply suggests that the rice farmers are over using seeds as an input in the production of rice. This finding supports that of Ajayi and Okunola (2006) who noted that the most discouraging thing among farm inputs is the cost of improved seeds. They observed that the cost seem to be increasing by the day and this will have a negative effect on the income of the farmers.

Table 7: Parameter Estimation of the Rice Inputs Provided and Income of the ALIS beneficiaries

\begin{tabular}{llll}
\hline $\begin{array}{l}\text { Explanatory } \\
\text { variables }\end{array}$ & $\begin{array}{l}\text { Unstandardized } \\
\text { Coefficients (B) }\end{array}$ & $\begin{array}{l}\text { Standardized } \\
\text { Coefficients } \\
\text { (Beta) }\end{array}$ & $\mathrm{t}$-value \\
\hline Constant & 11.049 & 0.858 & 86.474 \\
Farm size (ha) & $0.175^{*}$ & -0.188 & -2.624 \\
Cost of seeds & $-4.54-004^{*}$ & 0.139 & 1.978 \\
Cost of farm chemicals & $1.17 \mathrm{E}-005^{*}$ & \multicolumn{3}{c}{ Adjusted $R^{2}=0.798, F-$ statistics $=105.161$} \\
\multicolumn{4}{c}{ Significant at $1 \%$ level, Critical $F=6.63$}
\end{tabular}

Cost of farm chemicals is the third major determinant influencing the income level of the respondents. It has a beta value of 0.139 , with a $t-$ value of 1.978 and significant at the $5 \%$ level. The positive sign indicates the positive effect of farm chemicals use on rice income of the respondents. This report supports that of Nwakalobo (2000) who noted that an additional $\mathrm{kg} / \mathrm{ha}$ of fertilizer and urea applied to the soil would lead to an increase in soil nutrient level, resulting to increase in output level and consequently, an increase in the income of the farmers.

Extension agents' perception of the constraints facing the ALIS programme: The Extension agents perception of the ALIS programme constrains are shown on Table 8 . The major limitations facing the programme include the limited coverage of farmers with a mean of 3.23 , wrong selection of programme participants (3.22), late delivery of inputs by ADP (3.15) insufficient capital or poor funding of the programme (3.05) and low loan repayment rate by farmers (3.00). Other constraints include ineffectiveness of the inputs supplied to farmers e.g. fertilizers, urea and modern rice mills (2.97), community interference in the programme (2.83) and small volume of loan given farmers (2.77). These results support that of Agidi (1993) and Imolehin and Wada (2000) and Iheanacho and Mshelia (2004), They found that variables like late delivery of inputs, insufficient capital or poor funding of agricultural programmes, low loan repayment rates by farmers, ineffectiveness of the inputs supplied to farmers and insufficiency of loan given to farmers to be constraints facing rice production in Nigeria.

Table 8: Extension agents' perceptions of the constraints facing the ALIS programme

\begin{tabular}{lll}
\hline Problems & Mean & Standard Deviation \\
\hline Limited coverage of farmers & $3.23^{*}$ & 0.67 \\
Wrong selection of programme participants & $3.22^{*}$ & 0.78 \\
Late delivery of inputs by ADP & $3.15^{*}$ & 0.58 \\
Insufficient capital or poor funding of the & & \\
Programme & $3.05^{*}$ & 0.87 \\
Low loan repayment rate by farmers & $3.00^{*}$ & 1.09 \\
Ineffectiveness of the inputs supplied & $2.97^{*}$ & 1.02 \\
Community interference in the programme & $2.83^{*}$ & 0.89 \\
Small volume of loan & $2.77^{*}$ & 1.08 \\
Pest and disease invasions of farms & 2.22 & 0.74 \\
\hline \multicolumn{2}{l}{ *Regular (mean > 2.50), Source: Field survey, 2012 }
\end{tabular}

Conclusion and Recommendations: The average rice output of participants was $840 \mathrm{~kg}$ and $663.8 \mathrm{~kg}$ respectively. The difference in output $(176.25 \mathrm{~kg})$ was significant at the $1 \%$ level with a t- value of 4.992 , suggesting that the ALIS programme has contributed positively and significantly to increases in output of rice farmers in the study area. The income distribution shows that the average annual earnings was $\$ 140,478$ (participants) and $\$ 86,979$ (non- participants) with a difference of $\$ 53,468.75$. The ttest result $(\mathrm{t}=9.831)$ shows the difference was significant at the $1 \%$ level, meaning that the ALIS programme has contributed positively and significantly to increases in farm income.

The regular functions carried out by the extension agents in the ALIS programme were advisory role $($ mean $=2.75)$, farmer training on input use $(2.67)$

\footnotetext{
${ }^{*}$ OKWUOKENYE, GF; DU. OKOEDO-OKOJIE
} 
and demonstrating input use (2.65). The socio economic characteristics of the extension agents influencing the farmers' output and income are gender, age, marital status, educational level, houseold size, working experience and the extension agents' participation in the programme. Of them all, the extension agents' participant status plays a more significant role in the farmers' output and income. The inputs provided by the programme through the extension agents contributed significantly to the output and income of the farmers.

In the view of extension agents, important constraints facing the programme were limited coverage of farmers $($ mean=3.23), wrong selection of programme participants (3.22), late delivery of inputs (3.15), poor funding of the programme (3.05), low loan repayment rate by farmers (3.00), ineffectiveness of the inputs supplied (2.97), community interference in the programme (2.83) and small volume of loan (2.77).

Based on findings the following recommendations are put forward. There is a need for the implementers of the programme to ensure a timely release of the inputs (e.g. improved seeds, fertilizers, urea, sprayer and modern rice mill) used for the programme. Inputs like NPK 15:15:15 fertilizer supplied to the farmers were grossly inadequate. The ADP to this end should work specifically at how this can be ratified. The participants noted the threats from host communities because land acquired for the programme by government was not properly done. The government should seek to acquire land through genuine and legal land reclamation procedures. Effort should be made by the government to increase the loan size given to farmer participants. This is to enable them meet up with cost of producing rice. There is a need to ensure that only those farmers who depend on rice farming as source of livelihood are selected to participate in the programme.

\section{REFERENCES}

Adams, M. E. (1992). Agricultural Extension in Developing Countries. Longman publishing group ltd., United Kingdom. PP 89 - 92

Adeniyi, J.P. (2002). Farm size and resource -use efficiency in small scale agricultural production. The case of rice farms in Kwara State of Nigeria. Agricultural Journal. 23 (2):43 -50

Agbamu, J.U. (1993). Analysis of farmers characteristics associated with adoption of soil management innovations in Ikorodu L.G. A. of
Lagos State, Nigeria. Journal of Rural Extension Development. 1(2): 51-67.

Agidi, G. (1993). The Making of Practical Engineer. Sunday Tide. January 10: PP 11.

Agumagu, A.C. and Nwaogwugwu, O.N. (2006). Extension agents' commitment to extension work in Abia and Rivers States, Nigeria. A Journal of Agricultural Extension. 2 (1): 51 - 59.

Ajayi, M.T. and Okunlola, J.O. (2006). Farmers perceived agricultural input factors influencing adoption and production of food crops in Akure Area of Ondo State, Nigeria. Journal of Agricultural Extension. 2(1):1 - 7 .

AWC (2006). Africa Women Championship. Special Souvenir(Magazine). $5^{\text {th }}$ Edition of the championship held in Delta State, Nigeria. A Special Publication of the Delta State Sports Organizing Committee of the Championship. PP $10-19$

Boumas, G. (1994). Grain Storage, Elsevier Science Publishing Company, Amsterdam. PP 9 - 10.

DADP (2001). Delta State Agricultural Development Programme, Field Report. PP 3-5.

Eicher, C. K. (2001). “Africa's unfinished business: Building a sustainable agricultural research systems". Staff papers 2001 - 2010. Department of Agricultural Economics, Michigan State University, East Lansing Michigan.

Erie, A. P. (2009). A conceptual framework for the privatization and commercialization of agricultural extension services: A case study of Edo State, Nigeria. Rudel printers and publishers, Edo State, Nigeria. PP 1, 4, 25

Eze, C.C., Ibekwe, U.C., Peter O., Nwajiuba, C.U. (2006). Determinants of adoption of improved cassava production technologies among farmers in Enugu State of Nigeria. Journal or Agricultural Extension. 2(1): 37 -44.

Iheanacho, A.C. and Mshelia, S.I (2004) The economics of retail and wholesale local rice marketing in Adamawa State of Nigeria, 2004 annual conference, of the Nigerian Association of Agricultural Economics, Dept of Agricultural Economics and Rural Sociology, ABU, SamaruZaria. PP 1 - 5.

\footnotetext{
${ }^{*}$ OKWUOKENYE, GF; DU. OKOEDO-OKOJIE ${ }^{2}$
} 
Imolehin, E.D. and Wada A.C. (2000). Meeting the rice production and consumption demands of Nigeria with improved technologies. International Rice Commission Newsletter. 19: PP 1-11.

MANR (1998). Information Handbook. Ministry of Agriculture and Natural Resources, Abuja, Nigeria. PP $20-23$

Mgbada, J.U. (2006). Effectiveness of information sources on improved farming practices to women farmers in Enugu State, Nigeria. A Journal of Agricultural Extension. 2 (1): 67 -76.

Nwakalobo, A. B.S. (2000). Resource productivity and allocation efficiency in small holder coffee farmers in Rugwe district, Tanzania. Retrieved at http://www.fiuc.org/iaup/sap. $\quad$ February 23, 2008.
Olayemi, J.K (1998). Elements of applied econometrics. Elshadai Global ventures, ltd. PP 24

Sanusi, J.O (2003). Sustainable rice production in Nigeria. Seminar presentation held in Kaduna on $14^{\text {th }}$ and $15^{\text {th }}$ of January, 2003. Retrieved at http. II www. Oryza-Nigeria rice report. mht. February 26, 2008.

Yomi -Alfred, S.D. (2005). Measurement of farm households' socio-economic and sociopsychological variables: A paradigm for evolving a more appropriate method. Journal of Agriculture and social research (JASR). 5 (1): 90-95 